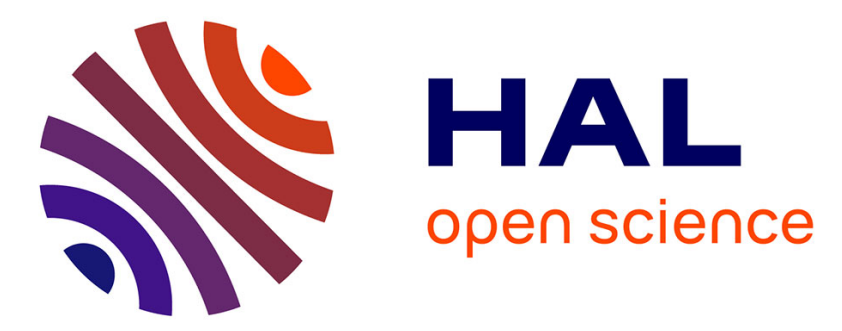

\title{
Assessment of Risk Management Practices in the Public Sector of Malaysia
}

\author{
Jamaliah Said, Md. Mahmudul Alam, Razana Juhaida Johari
}

\section{To cite this version:}

Jamaliah Said, Md. Mahmudul Alam, Razana Juhaida Johari. Assessment of Risk Management Practices in the Public Sector of Malaysia. International Journal of Business and Emerging Markets, 2020, 12 (4), pp.377-390. 10.1504/IJBEM.2020.10032965 . hal-03520137

\section{HAL Id: hal-03520137 https://hal.science/hal-03520137}

Submitted on 10 Jan 2022

HAL is a multi-disciplinary open access archive for the deposit and dissemination of scientific research documents, whether they are published or not. The documents may come from teaching and research institutions in France or abroad, or from public or private research centers.
L'archive ouverte pluridisciplinaire HAL, est destinée au dépôt et à la diffusion de documents scientifiques de niveau recherche, publiés ou non, émanant des établissements d'enseignement et de recherche français ou étrangers, des laboratoires publics ou privés. 


\title{
Assessment of Risk Management Practices in the Public Sector of Malaysia
}

\author{
Jamaliah Said \\ Accounting Research Institute \\ Universiti Teknologi MARA \\ Shah Alam, Malaysia \\ Email: jamaliah533@uitm.edu.my
}

\author{
Md. Mahmudul Alam* \\ School of Economics, Finance and Banking \\ Universiti Utara Malaysia \\ E-mail: rony000@gmail.com
}

\author{
Razana Juhaida Johari \\ Faculty of Accountancy \\ Universiti Teknologi MARA \\ Shah Alam, Malaysia \\ Email: razana@uitm.edu.my
}

*correspondent author

\section{Citation Reference:}

Said, J., Alam, M.M., \& Johari, R.J. (2020). Assessment of Risk Management Practices in the Public Sector of Malaysia, International Journal of Business and Emerging Markets, 12(3), 377-390. (online) https://www.doi.org/10.1504/IJBEM.2020.10032965

This is a pre-publication copy.

The published article is copyrighted by the publisher of the journal. 


\title{
Assessment of Risk Management Practices in the Public Sector of Malaysia
}

\begin{abstract}
Public sectors around the world, especially in the developing counties, are not functioning well due to widespread fraud, governance, corruption, and inefficacy. For this reason, the world's public sectors need to improve their efficacy by using a sound risk management system. This study attempts to comprehend the phenomenon of current risk management practices among the public sector employees in different service schemes in Malaysia. A questionnaire survey was utilized to collect primary data from 194 department heads in Malaysia's federal ministries. The collected data was analysed using descriptive statistics and factor analysis. Findings revealed that $94.7 \%$ of respondents agreed to implementing risk management in their respective departments, but the level of priority for these risk management factors differs based on the service schemes. This study will assist policymakers to identify what is needed to enhance risk management practices in the public sector.
\end{abstract}

Keywords: Pubic Sector, Risk Management, Factor Analysis, Malaysia

\section{Introduction}

Risk is integral in both public life and in business and it is part and parcel of many organizational activities and management (Tchankova, 2002). In general, risk is defined as the potential danger, injury, loss, and other unwanted outcomes (Rasid, Rahman, \& Ismail, 2011). Risk appears as the environment where a business operates becomes more and more uncertain, volatile, unpredictable, and unstable (Smallman, 1996; Abdullah et al., 2015). According to Tummala and Achoenherr (2011), risk involves the joint potential or frequency of a stated danger occurring and the outcome's magnitude. Risk is usually linked to an unwanted or unpredicted loss such as a negative and uncertain consequence (Tummala \& Achoenherr, 2011).

The major component of what an organization does is risk management and the objective is to ensure that all other activities related to management directly achieve the organization's objectives efficiently (Tchankova, 2002). Likewise, Archbold (2005) states in his study that risk management involves a process utilized to recognize possible liabilities and risks which could lead to potential loss to both private and public organizations. Carvalho and Rabechini (2015) describe risk management as uncertainty management in projects. Thus, to deal with risks in the current atmosphere of corporate scandals and the increasing density of global networks, knowledge management is a major mechanism for managing risks (Neef, 2005). The increase in business scandals such as financial crises and unpredictable downfalls of many large corporations and financial institutions in the US has led to dire consequences. These include declining economic activities, public losing confidence in corporations and a volatile financial system ( $\mathrm{Ng}$ et al., 2013).

Worldwide legislative reforms have been seen due to the increase in concerns on practices of risk management. The Malaysian Central Bank (BNM) has also changed some financial regulatory measures to incorporate corporate governance values into the financial services sector ( $\mathrm{Ng}$ et al., 2013). Consequently, the risk management concept, corporate governance, as well as internal controls are closely connected while the committee tasked to deal with risk management acts as the main governance mechanism to help the management and board manage such risks (Ng et al., 2013). Barafort et al. (2017) state that the IT settings of an organization play a significant role in risk management. 
Risk management is directly dependent on the changes that occur in an organization's internal as well as external environment since the environmental changes need continuous attention to identify and manage risks (Tchankova, 2002). In a practical way, several strategies concerning risk management are available but they greatly vary depending on the type of organization such as the management styles and organizational objectives (Archbold, 2005). Said et al. (2016) suggest that risk management strategies that are effective are expected to assist an organization to achieve its business goals while simultaneously improving the responsibility of financial reporting and maintaining a good reputation. However, prior studies mostly focused on risk management in the private sector as well as secondary data and this present study seeks to narrow this gap in our knowledge as much as possible (Wiengarten et al., 2016; Iwona, 2016; Ali et al., 2017).

Although risk management strategies differ based on what organizations do, the five stages of risk management, i.e. identification of risk, measuring risk, assessing risk, evaluating risk, as well as risk controls and monitoring, are still suitable and applicable to all institutions (Archbold, 2005). Likewise, studies carried out by Tummala and Leung (1996), Tummala and Achoenherr (2011), Rasid et al. (2011) and Giannakis and Papadopoulos (2016), reveal a similar outcome in terms of the steps taken in risk management involving identification of risk, risk measurements, assessment, analysis of risk and evaluation of risk, and risk controls thus defined as the risk management process or RMP. This study examines the risk management practices in the public sector of Malaysia. This study chose Malaysia due to the many recent concerns that are now very evident in its public sector with reports of corruption, fraud, governance failures, poor financial management, etc. These events have raised numerous questions about the accountability of the public sector in its obligation to uphold the public's trust. This study hopes to help the government to find those factors that can nurture and promote the value of accountability employing sound risk management practices.

\section{Research Methodology}

\section{Data Collection and Sampling}

Data collection was carried out from January to June 2016 and involved distributing a face-toface questionnaire survey to department heads from 6 Malaysian federal ministries. The 6 ministries are the Ministry of Communication and Multimedia, the Ministry of Education, the Ministry of Health, the Ministry of Defence, the Ministry of Agriculture and Agro-Based Industry and the Ministry of Rural and Regional Development. These ministries were selected because they have been often reprimanded in the Report by the Auditor General for three consecutive years from 2012 to 2014 due to issues including accountability, integrity, ethics, as well as mismanagement. Furthermore these 6 ministries include a total of 402 subdepartments. The study targeted 210 samples utilizing the systematic random sampling approach, and including 2 listed departments in every ministry. The selection was carried out beginning from a department's second list, fourth list, sixth list, and so on to reach 402 and ended with 210 items in the samples. Finally, 194 questionnaires were used in the data analysis from the 210 target samples.

Table 1: Distribution samples in the Malaysian ministries and departments

\begin{tabular}{|c|c|c|}
\hline Ministries \& Departments & $\begin{array}{l}\text { No. of Projected } \\
\text { Sub-departments }\end{array}$ & $\begin{array}{l}\text { No. of Actual } \\
\text { Samples }\end{array}$ \\
\hline \multicolumn{3}{|l|}{ The Ministry of Communications and Multimedia } \\
\hline 1. Department of Broadcasting Malaysia & 13 & 10 \\
\hline
\end{tabular}


2. Department of Information Malaysia

10

\begin{tabular}{|c|c|c|}
\hline \multicolumn{3}{|l|}{ The Ministry of Education } \\
\hline 3. Education Department of Johor & 10 & 10 \\
\hline 4. Education Department of Kelantan & 10 & 10 \\
\hline 5. Education Department of Labuan & 10 & 10 \\
\hline 6. Education Department of Pahang & 10 & 10 \\
\hline 7. Education Department of Perak & 10 & 10 \\
\hline 8. Education Department of Putrajaya & 10 & 10 \\
\hline 9. Education Department of Sabah & 10 & 5 \\
\hline 10. Education Department of Selangor & 10 & 10 \\
\hline \multicolumn{3}{|l|}{ The Ministry of Health } \\
\hline 11. Health Department of Perlis & 6 & 6 \\
\hline 12. Health Department of Selangor & 6 & 6 \\
\hline 13. Health Department of Terengganu & 6 & 6 \\
\hline 14. Health Department of Sarawak & 6 & 6 \\
\hline 15. Health Department of Kuala Lumpur & 6 & 6 \\
\hline 16. Health Department of Perak & 6 & 6 \\
\hline 17. Health Department of Melaka & 6 & 6 \\
\hline 18. Health Department of Kedah & 6 & 6 \\
\hline \multicolumn{3}{|l|}{ The Ministry of Defence } \\
\hline 19. Department of Veteran Affairs & 7 & 5 \\
\hline \multicolumn{3}{|l|}{ The Ministry of Agriculture and Agro-based Industry } \\
\hline 20. Fishery Department & 13 & 10 \\
\hline 21. Agriculture Department & 12 & 12 \\
\hline \multicolumn{3}{|l|}{ The Ministry of Rural and Regional Development } \\
\hline 22. Community Development Department & 12 & 12 \\
\hline $\begin{array}{l}\text { 23. Rubber Industry Smallholders Development } \\
\text { Authority }\end{array}$ & 15 & 12 \\
\hline Total & 210 & 194 \\
\hline
\end{tabular}

\subsection{Measurements of Variables}

Each respondent was asked to provide their perspective on the practices which promote management of risk in their departments using a five-point Likert scale ranging from 1 (strongly disagree) to 5 (strongly agree). Table 2 shows the risk management that was measured utilizing the 12 items adapted from Mancuso's (2012) study.

Table 2: Factors of risk management measurement in the public sector of Malaysia

\begin{tabular}{|c|c|}
\hline Code & Description of Items \\
\hline RM1 & My department has a risk management policy in place. \\
\hline RM2 & $\begin{array}{l}\text { My department consults subject matter experts and representatives from all areas of } \\
\text { organizations to develop the risk management policy. }\end{array}$ \\
\hline RM3 & $\begin{array}{l}\text { The policy and all procedures and training that the department has in place are being well } \\
\text { documented. }\end{array}$ \\
\hline RM4 & $\begin{array}{l}\text { My department reviews risk management policy annually/after department changes/after } \\
\text { experiencing a risk. }\end{array}$ \\
\hline RM5 & $\begin{array}{l}\text { My department trained the staff and third party collaborators on the risk management } \\
\text { policy. }\end{array}$ \\
\hline RM6 & My department takes a risk in seizing and exploiting new opportunities. \\
\hline RM7 & My department makes large, bold decisions despite uncertainty. \\
\hline RM8 & My department considers our organizational strategic are well specified. \\
\hline RM9 & My department is monitoring government priorities. \\
\hline RM10 & My department is focusing most of its attention on driving organizational success. \\
\hline RM11 & My department is keeping up to date with international developments/ technologies. \\
\hline
\end{tabular}




\subsection{Data Analysis}

The collected data was analysed using the descriptive statistics and factor analysis techniques made possible by SPSS (Lamash \& Josman, 2020; Tekler et al., 2019). Descriptive statistics are normally utilized to analyse the overall features of the data while factor analysis serves to calculate data consistency in a study. Data reliability is measured through the Cronbach's alpha test and data normality is examined using the skewness and kurtosis tests. Lastly, data validity is tested with the Kaiser-Meyer Olkin test and Barlett's test.

\section{Findings and Discussion}

\subsection{Demographic Profiles}

Relevant demographic information was gathered from the respondents such as ethnicity, gender, age, academic qualification, type of qualification, job position, department, grade, as well as length of employment. A summary of the demographic information is shown in Table 3.

Table 3: Respondents' demographic information

\begin{tabular}{|c|c|c|c|}
\hline \multicolumn{2}{|c|}{ Demographic Profiles } & \multirow{2}{*}{$\begin{array}{c}\begin{array}{c}\text { Frequency } \\
\text { (N=194) }\end{array} \\
79\end{array}$} & \multirow{2}{*}{$\begin{array}{c}\begin{array}{c}\text { Percentage } \\
(\%)\end{array} \\
40.7\end{array}$} \\
\hline Gender & Male & & \\
\hline & Female & 115 & 59.3 \\
\hline \multirow[t]{3}{*}{ Ethnicity } & Malay & 176 & 90.7 \\
\hline & India & 11 & 5.7 \\
\hline & Chinese & 7 & 3.6 \\
\hline \multirow[t]{4}{*}{ Age } & $20-30$ years & 24 & 12.4 \\
\hline & $31-40$ years & 64 & 33.0 \\
\hline & $41-50$ years & 74 & 38.1 \\
\hline & 51 years and above & 32 & 16.5 \\
\hline \multirow[t]{3}{*}{ Academic Qualifications } & Degree & 100 & 51.5 \\
\hline & Master & 90 & 46.4 \\
\hline & $\mathrm{PhD}$ & 4 & 2.1 \\
\hline \multirow[t]{2}{*}{ Types of Qualifications } & Accounting & 98 & 50.5 \\
\hline & Non-Accounting & 96 & 49.5 \\
\hline \multirow[t]{4}{*}{ Job Position } & Supporting Staff & 7 & 3.6 \\
\hline & Management and & 176 & 90.7 \\
\hline & Professional & & \\
\hline & Top Management & 11 & 5.7 \\
\hline \multirow[t]{5}{*}{ Department } & Accounting & 45 & 23.2 \\
\hline & Administrative & 78 & 40.2 \\
\hline & Audit & 10 & 5.2 \\
\hline & Finance & 46 & 23.7 \\
\hline & Others & 15 & 7.7 \\
\hline \multirow[t]{4}{*}{ Grade } & 41 & 101 & 52.1 \\
\hline & 44 & 21 & 10.8 \\
\hline & 48 & 70 & 36.1 \\
\hline & 52 & 2 & 1.0 \\
\hline \multirow{4}{*}{$\begin{array}{l}\text { Length of Employment in the } \\
\text { Current Organization (no. of } \\
\text { years) }\end{array}$} & Less than 1 year & 11 & 5.7 \\
\hline & $1-3$ years & 10 & 5.2 \\
\hline & $4-5$ years & 23 & 11.9 \\
\hline & 5 years and above & 150 & 77.3 \\
\hline
\end{tabular}


The table shows that $59.3 \%$ of the respondents are female while $38 \%$ of them are in the $41-50$ age bracket with 33\% being in the 31-40 age bracket. Most of the respondents are Malays and they account for $90.7 \%$. All the respondents possessed a basic Bachelor degree qualification. $90.7 \%$ of the respondents' job positions are as management professionals. As much as $40 \%$ of the respondents work in the administrative area while $23.7 \%$ of them are in the financial services, and only $5.2 \%$ work in accounting. The remaining $7.7 \%$ work in other departments as officers in the legal, tax, education, health, procurement, and IT departments. Just over half of the respondents $(52.1 \%)$ belong to Grade 41 , while Grade 48 comprises $36.1 \%$ respondents and Grade 44 has 10.8\%. 77\% have been working for more than 5 years in the present organization while only $12 \%$ have been working for 4 to 5 years in the present organization.

\subsection{Factor Analysis}

The variables' consistency is determined by using factor analysis to establish the risk management. All the variables' factor loadings in this study are more than 0.6 with the exception of items RM10 and RM12 as shown in Table 4. Therefore, following the removal of these two variables, the values of the factor loading range from 0.6 (RM9) to 0.88 (RM7). This demonstrates that 10 out of the 12 variables can measure risk management in Malaysia's public sector.

\subsection{Descriptive Analysis}

\subsubsection{Service Scheme-wise Evaluation}

According to all the service scheme groups, the highest average outcome for the factors of risk management is at 4.4 , including the practices undertaken by the administration and finance schemes group. Meanwhile the lowest mean score is at 4.1, including what the accounting and audit schemes group do (Table 4). Moreover, the overall average score for risk management is 4.3 .

Table 4: Risk Management factors according to service schemes

\begin{tabular}{|c|c|c|c|c|c|c|c|c|c|c|c|c|c|}
\hline $\begin{array}{l}\text { Service } \\
\text { Schemes }\end{array}$ & RM1 & RM2 & RM3 & RM4 & RM5 & RM6 & RM7 & RM8 & RM9 & RM10 & RM11 & RM12 & $\begin{array}{c}\text { All } \\
\text { Average }\end{array}$ \\
\hline Accounting & 4.0 & 4.1 & 4.3 & 4.2 & 4.2 & 4.0 & 3.8 & 4.0 & 4.1 & 4.3 & 4.3 & 4.2 & 4.1 \\
\hline Administration & 4.4 & 4.4 & 4.6 & 4.7 & 4.6 & 4.3 & 4.0 & 4.4 & 4.3 & 4.3 & 4.7 & 4.7 & 4.4 \\
\hline Audit & 4.1 & 4.0 & 4.4 & 4.0 & 4.0 & 3.5 & 3.7 & 4.1 & 4.1 & 4.2 & 4.2 & 4.5 & 4.1 \\
\hline Finance & 4.4 & 4.4 & 4.5 & 4.6 & 4.6 & 4.3 & 4.0 & 4.3 & 4.4 & 4.4 & 4.6 & 4.5 & 4.4 \\
\hline Others & 4.3 & 4.2 & 4.1 & 4.4 & 4.2 & 4.4 & 3.9 & 4.1 & 4.1 & 4.3 & 4.4 & 4.3 & 4.2 \\
\hline All Average & 4.3 & 4.3 & 4.5 & 4.5 & 4.4 & 4.2 & 3.9 & 4.2 & 4.3 & 4.3 & 4.5 & 4.5 & 4.3 \\
\hline $\begin{array}{l}\text { Factor } \\
\text { Loading }\end{array}$ & 0.71 & 0.74 & 0.63 & 0.80 & 0.74 & 0.77 & 0.88 & 0.74 & 0.60 & 0.43 & 0.69 & 0.12 & \\
\hline
\end{tabular}

* The factor loadings of the parameters less than 0.6 are considered not suitable for measuring risk management in the Malaysian public sector

The accounting service scheme group has a total average score of 4.1, with the highest score being 4.3 for RM3, RM10, as well as RM11. Factors RM1, RM6, and RM8 show scores that are smaller in comparison to the average total scores. The administrative scheme group has a total average score of 4.4 with the highest score being 4.7 for RM4, RM11, as well as RM12, and RM7 factor has the lowest score at 4.0. Moreover, RM6, RM9, and RM10 indicate scores that are smaller in comparison to the average total scores. The overall risk management score for the audit scheme group is 4.1, with factors RM6 and RM7 scoring only 
3.5 and 3.7, respectively. The RM12 factor had the highest score at 4.5. As well, the RM7 score is smaller when compared to the average scores. Lastly, the finance scheme group has a total average score of 4.4 with RM4, RM5, and RM11 factors having the highest scores at 4.6, while RM7 factor has the lowest score at 4.0. In addition, RM6 and RM8 scores are smaller in comparison to the average scores.

\subsubsection{Factor-wise Evaluation}

This study aims to measure the practices of risk management in the public sector by utilizing 12 variables. According to the participants' responses, $94.7 \%$ agreed that they implement the stated factors of risk management while $2.2 \%$ responded that they did not, as revealed in Table 5. All the factors of risk management reveal that factors RM3, RM4, RM11, as well as RM12 have the highest mean score at 4.5. Meanwhile, factor RM7 has the lowest mean score at 3.9 as stated in Table 4 .

Table 5: Frequency scores of risk management factors

\begin{tabular}{|c|c|c|c|c|c|c|c|c|c|c|c|c|c|}
\hline Score & RM1 & RM2 & RM3 & RM4 & RM5 & RM6 & RM7 & RM8 & RM9 & RM10 & RM11 & RM12 & $\begin{array}{c}\text { All } \\
\text { Average }\end{array}$ \\
\hline 1 & 0 & 0 & 0 & 4 & 4 & 4 & 0 & 0 & 0 & 0 & 0 & 0 & 1.0 \\
\hline 2 & 5 & 4 & 4 & 1 & 1 & 1 & 6 & 4 & 4 & 0 & 5 & 4 & 3.3 \\
\hline 3 & 2 & 7 & 4 & 3 & 13 & 10 & 12 & 9 & 3 & 6 & 1 & 3 & 6.1 \\
\hline 4 & 124 & 117 & 80 & 73 & 63 & 113 & 168 & 117 & 127 & 121 & 73 & 80 & 104.7 \\
\hline 5 & 63 & 66 & 106 & 113 & 113 & 66 & 8 & 64 & 60 & 67 & 115 & 107 & 79.0 \\
\hline Disagree (1-2) & 5 & 4 & 4 & 5 & 5 & 5 & 6 & 4 & 4 & 0 & 5 & 4 & 4.3 \\
\hline Agree (4-5) & 187 & 183 & 186 & 186 & 176 & 179 & 176 & 181 & 187 & 188 & 188 & 187 & 183.7 \\
\hline Disagree $(1-2) \%$ & 2.6 & 2.1 & 2.1 & 2.6 & 2.6 & 2.6 & 3.1 & 2.1 & 2.1 & 0.0 & 2.6 & 2.1 & 2.2 \\
\hline Agree (4-5) \% & 96.4 & 94.3 & 95.9 & 95.9 & 90.7 & 92.3 & 90.7 & 93.3 & 96.4 & 96.9 & 96.9 & 96.4 & 94.7 \\
\hline Minimum & 2 & 2 & 2 & 1 & 1 & 1 & 2 & 2 & 2 & 3 & 2 & 2 & 2 \\
\hline Maximum & 5 & 5 & 5 & 5 & 5 & 5 & 5 & 5 & 5 & 5 & 5 & 44 & 7 \\
\hline Std. Dev. & 0.6 & 0.6 & 0.6 & 0.7 & 0.8 & 0.7 & 0.5 & 0.6 & 0.6 & 0.5 & 0.6 & 0.6 & 0.5 \\
\hline
\end{tabular}

According to the factors of risk management practices in the public sector, $96.4 \%$ of the respondents revealed they have a risk management policy in place (RM1) as shown in Table 5. The employees in the administrative and finance schemes perceived it to be the highest while the employees from the accounting scheme regarded it as the least as shown in Table 4. Compared to the remaining service schemes, employees from the audit scheme perceived it as being less than the average score.

Furthermore, $94.3 \%$ of participants agreed that their departments consult subject matter experts and representatives from all areas of organizations to develop risk management policy (RM2) as demonstrated in Table 5, and employees from the administration and finance scheme deemed it to be the highest while those from the audit scheme regarded it the lowest according to Table 4. According to the results from the other service schemes, employees from accounting perceived it to be less than the average.

Table 5 shows that $95.9 \%$ of the respondents agree that the policy and all the procedures and training that the department has in place are being well documented (RM3). The employees under the administrative scheme claim it to be the highest and employees under the accounting scheme claim it is the least as shown in Table 4. According to the results from the remaining service schemes, respondents from the audit scheme regard as less than the average level. Table 5 shows that $95.9 \%$ of the respondents agree with review risk management policy annually/after department changes/after experiencing a risk (RM4). The 
respondents under the administrative scheme perceive it to be highest while respondents from the audit scheme believe it is the least as shown in Table 4. Referring to the results for the remaining service schemes, respondents from the accounting scheme regard them to be less than the average level.

Table 5 shows that $90.7 \%$ of the respondents agree that they trained the staff and third party collaborators on the risk management policy (RM5). The respondents working in the administrative and finance scheme perceive it to be the highest while respondents from the audit scheme claim it is the least as shown in Table 4. For the outcomes obtained from the remaining service schemes, respondents from accounting regard them to be less than the average level.

Table 5 shows that $92.3 \%$ of the respondents agree that they take risk in seizing and exploiting new opportunities (RM6). The respondents under the administrative and finance scheme perceive it to be highest and respondents from the audit scheme claim it to be the least as shown in Table 4. According to the results from the remaining service schemes, respondents from the accounting scheme believe them to be less than the average level.

Table 5 shows that $90.7 \%$ of the respondents agree they make large, bold decisions despite uncertainty (RM7). The employees under the administrative and finance scheme practice it the most and respondents from the audit scheme practice it the least as shown in Table 4. From the remaining service schemes, the results show that respondents from the accounting scheme practice it less than the average level.

Table 5 indicates $93.3 \%$ of the respondents agree that their strategic are well specified (RM8). The respondents under the administrative scheme practice it the most and respondents from the accounting scheme practice it the least as reported in Table 4. According to the results from the remaining service schemes, respondents in auditing practice it less than the average level.

Table 5 reveals that $96.4 \%$ of the respondents agree they are monitoring government priorities (RM9). The respondents under the finance scheme practice it the most and respondents from the accounting and audit scheme practice it the least as shown in Table 4.

Finally, Table 5 shows that $96.9 \%$ of the respondents agree they are keeping up to date with international developments/ technologies (RM11). The respondents under the administration scheme practice it the most while respondents from the audit scheme practice it the least as shown in Table 4.

\subsection{Diagnostic Tests}

The normality testing was carried using the skewness and kurtosis tests. Skewness refers to something that is out of the norm based on the curve's extension, whether it curves out to the left or right. It is identified as being positively skewed if the curve extends to the right more, and negatively skewed if it extends to the left more (Wuensch, 2014). Moreover, Kurtosis provides the measurement of the flatness of the symmetric distribution at the top. The rule of thumb is that both the skewness and kurtosis_are regarded as being normally distributed if the values are between -2 to +2 . The distribution of the data is regarded as being normal if the values of the skewness and kurtosis are within this range. However, the skewness value in this study is -1.836 and the kurtosis value is 17.5 , which shows being outside the range of 
normality or in other words the data is not distributed normally. Nevertheless, Field (2013) explains that the data can be regarded as normal if it exceeds thirty and in this study the sample size is 194 .

Table 6: Reliability testing for risk management factors

\begin{tabular}{lr}
\hline Cronbach's Alpha & 0.896 \\
Eigenvalue & 8.23 \\
Eigen \% variance & 82.31 \\
\hline \% of variance & 82.31 \\
Kaiser-Meyer-Olkin Measure of Sampling Adequacy & 0.662 \\
Bartlett's Test of Sphericity Approx. Chi-Square & 2866.319 \\
Bartlett's Test of Sphericity Sig. & 0.00000 \\
\hline
\end{tabular}

The value of Cronbach's alpha on risk management as shown in Table 6 is 0.896 . It proves that the items' reliability in the questionnaire is excellent (George \& Mallery, 2016). The eigenvalues test indicates that the factors used for risk management are able to explain $82.31 \%$ of the variance. The Kaiser-Meyer Olkin test suggests a value higher than 0.6 , at 0.662. The Bartlett's Test of Sphericity Approx. Chi-Square indicates the significance of the value $($ Chi-Square $=2866, \mathrm{p}<0.0000001)$. Therefore, the sample is found to be adequate for continuing with the factor analysis so that the risk management can be calculated.

\section{Conclusions and Recommendations}

Malaysia has envisioned becoming a properly functioning developed country by the year 2020; as such, many good strategies have to be utilized to make this happen, especially for the level of risk management in the public service sector. This study has attempted to calculate the current level of risk management practices in the public sector in Malaysia through the use of 12 related factors. It emerged that $94.7 \%$ of the respondents asserted that they practice the stated factors of risk management, nevertheless, various service schemes prioritized the 12 factors differently. Overall, risk management practices in administration and finance schemes group were the highest in comparison to the other scheme groups. Meanwhile, risk management practices in the accounting and audit scheme group were lower in contrast to the general average score.

The Malaysian government continues to initiate programmes with the objective of promoting and motivating the risk management practices throughout the public sector and its departments so that they are much more transparent in their operations. Nevertheless, the anticipated effect has not been observed as reported in the Corruption Perception Index (CPI) by Transparency International in 2014, where Malaysia only went up in ranking by three points from 53 to 50 based on a survey of 175 countries. This confirms that the measures taken to overcome corruption in the country are still lacking (Zainal, 2014; Said et al., 2016; Alam et al., 2018). It demonstrates that even though the government has undertaken important steps to change what the public perceive, much more concerted effort is required to improve the public's confidence in the public sector's risk management practices.

It is not enough to simply transform the bureaucracy's structure to improve the current situation. The entire public sector must be changed to develop an efficient and dependable sector that can implement sufficient risk management practices backed by an efficient assessment system. Improving the risk management practices would certainly help achieve what the stakeholders want to ensure accountability in the public sector. It is recommended that every ministry and department reports and produces its risk management and ethical 
activities to make sure that a good governance culture is created and maintained. The report should be accessible to the public to develop a sense of awareness and to educate them on the critical steps that have been carried out to curtail misconduct by the government's employees.

The findings of this study could be utilized to assist the different agencies and departments to enhance their risk management levels based on the associated service schemes. Additionally, the risk management factors measures and methods used in this study could help the Malaysian government to create measurement techniques that document accountability in the public sector. However, this study also had to face some limitations that could be resolved in future research. This study only utilized six ministries for analysis although the Malaysian government has in total 24 ministries and the questionnaire was only given to department heads. The levels at which risk management is practised could differ based on the specific ministries and selecting officials of more varied rankings, which could be considered in future research.

\section{References}

Abdullah, M., Shukor, Z. A., Mohamed, Z. M. \& Ahmad, A. (2015). Risk management disclosure. Journal of Applied Accounting Research, Vol. 16(Iss 3), pp 400-432. doi: 10.1108/JAAR-10-2014-0106

Alam, M.M., Johari, R.J. \& Said, J. (2018). An Empirical Assessment of Employee Integrity in the Public Sector of Malaysia, International Journal of Ethics and Systems, 34(4), 458-471.

Ali, A., Warren, D., \& Mathiassen, L. (2017). Cloud-based business services innovation: A risk management model. International Journal of Information Management, 37(6), 639-649.

Archbold, C. A. (2005). Managing the bottom line: risk management in policing. Policing: An International Journal of Police Strategies \& Managment, Vol. 28(Iss 1), pp 30-48. doi: 10.1108/13639510510580968

Aziz, M. A. A., Rahman, H. A., Alam, M. M. \& Said, J. (2015). Enhancement of the Accountability of Public Sectors through Integrity System, Internal Control System and Leadership Practices: A Review Study. Procedia Economics and Finance, pp 163 - 169. doi: 10.1016/S2212-5671(15)01096-5

Barafort, B., Mesquida, A. L., \& Mas, A. (2017). Integrating risk management in IT settings from ISO standards and management systems perspectives. Computer Standards \& Interfaces, 54, 176-185.

Bianchi, C. (2010). Improving performance and fostering accountability in the public sector through system dynamics modelling: From an 'external' to an 'internal' perspective. Systems Research and Behavioral Science, 27(4), 361-384. doi: 10.1002/sres.1038

Carvalho, M. M. D., \& Rabechini Junior, R. (2015). Impact of risk management on project performance: the importance of soft skills. International Journal of Production Research, 53(2), 321-340.

Field, A. (2013). Discovering Statistics Using IBM SPSS Statistics. 4th Edition, SAGE Publications.

George, D., \& Mallery, P. (2016). IBM SPSS Statistic 23 Step by Step: A simple guide and reference. $14^{\text {th }}$ Edition, New York: Routledge, Taylor \& Francis.

Giannakis, M., \& Papadopoulos, T. (2016). Supply chain sustainability: A risk management approach. International Journal of Production Economics, 171, 455-470. 
Iwona, G. M. (2016). Leading risk management determinants of small and medium-sized enterprises (SMEs): An exploratory study in Poland. In Entrepreneurship, Business and Economics-Vol. 1 (pp. 289-298). Springer, Cham.

Lamash, L., \& Josman, N. (2020). Full-information factor analysis of the Daily Routine and Autonomy (DRA) questionnaire among adolescents with autism spectrum disorder. Journal of Adolescence, 79, 221-231.

Mancuso, M. (2012). Nonprofit Risk Management. The Philanthropist, Vol. 24(Iss 3), pp 191197.

Neef, D. (2005). Managing corporate risk through better knowledge management. The Learning Organization, Vol. 12(Iss 2), pp 112-124. doi: 10.1108/09696470510583502

Ng, T.-H., Chong, L.-L. \& Ismail, H. (2013). Is the risk management committee only a procedural compliance? The Journal of Risk Finance, Vol. 14(Iss 1), pp 71-86. doi: $10.1108 / 15265941311288112$

Rasid, S. Z. A., Rahman, A. R. A. \& Ismail, W. K. W. (2011). Management accounting and risk management in Malaysian financial institutions. Managerial Auditing Journal, Vol. 26(Iss 7), pp 566-585. doi: 10.1108/02686901111151314

Said, J., Alam, M.M., \& Khalid, M. (2016). Relationship between Good Governance and Integrity System: Empirical Study on the Public Sector of Malaysia. Humanomics, 32(2), 151-171.

Smallman, C. (1996). Risk and organizational behaviour: a research model. Disaster Prevention and Management: An International Journal, Vol. 5(Iss 2), pp 12-26. doi: $10.1108 / 09653569610112880$

Tchankova, L. (2002). Risk identification-basic stage in risk management. Environmental Management and Health, Vol. 13(Iss 3), pp 290-297. doi: 10.1108/09566160210431088

Tekler, Z. D., Low, R., Chung, S. Y., Low, J. S. C., \& Blessing, L. (2019). A Waste Management Behavioural Framework of Singapore's Food Manufacturing Industry using Factor Analysis. Procedia CIRP, 80, 578-583.

Tummala, R. \& Achoenherr, T. (2011). Assessing and managing risks using the Supply Chain Risk Management Process (SCRMP). Supply Chain Management: An International Journal, Vol. 16(Iss 6), pp 474-483. doi: 10.1108/13598541111171165

Tummala, V. M. R. \& Leung, Y. H. (1996). A risk management model to assess safety and reliability risks. International Journal of Quality \& Reliability Management, Vol. 13(Iss 8), pp 53-62. doi: 10.1108/02656719610128493

Wiengarten, F., Humphreys, P., Gimenez, C., \& McIvor, R. (2016). Risk, risk management practices, and the success of supply chain integration. International Journal of Production Economics, 171, 361-370.

Wuensch, K. L. (2014). Skewness, Kurtosis and the Normal Curve. http://core.ecu.edu/psyc/wuenschk/StatsLessons.htm

Zainal, H. (2014). Malaysia climbs up three places in Corruption Index, The Star, 3 December. Retrieve from http://www.thestar.com.my/news/nation/2014/12/03/cpimalaysia-50-improves-two-places/ 


\section{Author's Biography:}

Prof. Dr. Jamaliah Said is currently the Deputy Director of Accounting Research Institute, Universiti Teknologi MARA. She has published 100+ journal articles and presented 100+ articles in conferences. She is the managing editor of two eminent journals - Malaysian Accounting Review and Asia Pacific Management Accounting Review. Her main research interests are fraud, governance, accountability, and strategic management.

Dr. Md. Mahmudul Alam is an Associate Professor of Finance at Universiti Utara Malaysia. He is also an AFFP Research Fellow at FS-UNEP Centre (Germany), Associate Fellow at Centre for Asian Climate and Environmental Policy Studies (Canada) and Associate Fellow at University Technology MARA (Malaysia). He is recognized by the BDRC (USA) as one of the "Top Bangladesh Development Researchers of the Millennium". He obtained his PhD and Master's degrees from National University of Malaysia. To date he has published 125+ journal articles and presented 80+ articles at conferences. His research areas include sustainable finance, sustainable development, ecological economics, financial economics, fintech, and Islamic finance and economics.

Dr. Razana Juhaida Johari is an Associate Professor of Accounting at Universiti Teknologi MARA (UiTM), Malaysia. She is a member of Chartered Accountants, Malaysian Institute of Accountants, and serves as an Editorial Board Member of Canadian International Business Research (IBR) Journal, Jurnal Akuntansi Keuangan \& Bisnis, Associate Editor of Journal of Financial Reporting \& Accounting and Associate Fellow at the Australian World Business Institute (WBI). Her research interests are auditing, fraud, accounting ethics and governance. She also manages to collaborate with academic \& research members from international and national universities in joint conferences, seminars, research workshops, publications and academic visits. 